ETAC ABET accreditation and information literacy: A Case Study of Mechanical Engineering Technology

Mr. Michael Fosmire, Purdue University-Main Campus, West Lafayette (College of Engineering)

Michael Fosmire is Professor of Library Science and Head, Physical Sciences, Engineering, and Technology Division of the Purdue University Libraries. He has written over 40 articles and chapters on the role of information in active-learning pedagogies and the integration of information literacy in STEM curricula, including co-editing Integrating Information into the Engineering Design Process. 


\title{
ETAC ABET accreditation and information literacy: A Case Study of Mechanical Engineering Technology
}

\begin{abstract}
Much work has been done to determine how information literacy student outcomes can be assessed in ABET accredited engineering degree programs, but often overlooked are the Engineering Technology programs, whose graduates form an important layer in our modern workforce. This study gathers data from engineering librarians and MET departments to understand how information literacy competencies are assessed and what role the library plays in meeting those student and program outcomes. Results from a survey of MET liaison librarians show a wide variety of levels of involvement, from developing resource guides, to curricular and student consults, embedded classroom activities, and in-class instruction. Librarians make contributions to not only 3.g, an ability to apply written, oral, and graphical communication in both technical and non-technical environments; and an ability to identify and use appropriate technical literature; but also student outcomes 3.h, .i, .j, and .k, and the program criterion .h, application of industry codes, specifications, and standards. Most librarians composed or contributed to Section 7.E (Library Services) and met with the visiting committee. The ABET Self-study documents showed that the bulk of outcome 3.g data gathering for ABET occurs in capstone design courses, but that, generally speaking, several courses in a curriculum contribute to and assess that student outcome. While information is explicitly mentioned in the student outcome, it appears to frequently be marginalized in the actual assessments used by METdepartments. Implications for librarian engagement with mechanical engineering technology programs and sources are discussed.
\end{abstract}

\section{Introduction}

One way librarians can make the case for information literacy in engineering and engineering technology disciplines is to tie their work into student outcomes specified for ABET accreditation. For engineering accredited programs (EAC), there is not a direct link to information literacy. Rather, librarians have traditionally linked information literacy to lifelong learning, although Riley [1] and Sapp and Fosmire [2] have made the argument that information literacy can be integrated into a number of student outcomes. However, the engineering technology (ETAC) student outcomes changed around 2011 by explicitly mentioning information skills, extending the old 3.g, “ability to communicate effectively,” [3] to 3.g, "an ability to apply written, oral, and graphical communication in both technical and non-technical environments; and an ability to identify and use appropriate technical literature.” [4]

With this change to the student outcomes in engineering technology, there is the potential for new opportunities for collaboration between librarians and those programs. While the work of librarians in EAC programs has been well documented, for example, at every Engineering Librarians Division program at ASEE conferences, there has been quite limited examination of engineering technology programs. This may be because relatively fewer engineering technology programs exist than engineering programs, they tend to be smaller, and ET programs are more common at smaller institutions and branch or satellite campuses of larger institutions. Certainly, many of the ET associate degree programs are hosted at smaller institutions. These smaller 
institutions may have fewer resources for professional development, fewer libraries staff, which means one librarian may have to meet the needs of all STEM disciplines, and fewer requirements to publish and present than librarians at larger institutions.

Sapp and Fosmire [2] describe a process of engaging with an electrical engineering technology program as part of their curricular redesign, to incorporate information literacy components in support of achieving student outcomes. Two engineering technology faculty [5] surveyed students and found very little use of library resources, despite the library being "quite impressive regarding both its size and holdings." They observed that "if the library is indeed an underutilized resource, the survey results raise the question of how instructors in technical courses may encourage a fuller use of the library’s resources.”

Feldmann and Feldmann [6], a mechanical engineering technology professor and a librarian, collaborated to provide instruction to first year students and found they needed and valued an awareness of the kinds of resources available through the library and practice finding information in the library. Hill, Best, and Dalessio [7] conducted a literature review and found no articles dealing with information literacy related to engineering technology at junior and community colleges. They describe their own efforts to create an information literacy assessment program for EET at Erie Community College.

Erdmann and Harding [8], [9] have reported on a longstanding collaboration, the 'Treasure Hunt' to teach information literacy concepts to MET students, which was extended by Sapp, Van Epps, Fosmire, and Harding [10]. Bhatt, Genis, and Roberts describe a library program for Applied Engineering Technology students.[11] Some papers have discussed the integration of technical standards into engineering technology curricula [12]- [14], and Harding and McPherson discuss employers’ perspectives on standards skills needed by graduates [15].

Pinelli, England, Barclay, and Kennedy [16] reported on the technical communication practices of engineering technology students. They found that most students (from three institutions in the sample) had received library instruction, used library resources, and thought information skills would be important to their success professionally.

With this relative dearth of examination of the engineering technology academic sector, despite the explicit mention of information in engineering technology student outcomes, I wanted to see what the state of thinking was in engineering technology programs. How had institutions internalized the 'use of technical information' and incorporated it into their curriculum, and what roles have librarians played in attempting to facilitate it? In order to keep the data manageable, I focused on Mechanical Engineering Technology BS programs, as they not only have a requirement to meet the core student outcome, but there is also a student outcome specific to the MET program "Basic familiarity and use of industry codes, specifications, and standards" [17]. I gathered information from both librarians and ABET coordinators to get multiple perspectives on this question.

As a final note, just a comment about changes to the ABET student outcomes criteria. When this study was conducted, ABET was just moving from the 3.a-k criteria to 1-5 criteria, so I caught many institutions in the transition of thinking between the two systems. Thankfully, for this 
study, 3.g from the legacy outcomes was reproduced exactly as outcome 3 in the new system [18]. Thus, the research question was still relevant for institutions going forward. Since I was asking for self-study information, the old terminology of 3.g was still in effect, so the documentation gathered and discussed here reflects the old terminology.

\section{Methods}

ETAC accredited MET bachelor's level degree programs were identified from the ABET web site (www.abet.org/accreditation/find-programs) in October 2018. I identified 66 accredited programs. The coordinator of each program was identified from those institutions' web sites, as well as the liaison to the Mechanical Engineering Technology program at that institution. Where a program coordinator was not apparent, the department chair, or main contact information from the department were identified. Emails were sent to the contacts for each institution, with one follow-up reminder to respond (see Appendix A). The emails asked for information from the institution's latest self-study related to the 3.g student outcome related to written, oral, and graphical communication and the ability to identify and use appropriate technical literature. Since the self-studies are confidential, there is no systematic way to gather information about institutional practices. I am indebted to the institutions who did take the time to answer requests for this information.

I also identified the liaison librarian to Mechanical Engineering Technology from each institution, by searching the institution's library web site. Where an explicit MET liaison was not indicated, a likely candidate was identified (e.g., if there was only one STEM librarian in the library), and as a last choice, the library director was identified as the point of contact. A survey was distributed to the so-identified library representative of each institution, using the Qualtrics survey program (see Appendix B). An email invitation to the survey was sent as well as one reminder.

The information provided by MET departments varied in depth and type, so a systematic analysis was challenging. Thus, the results of the information are more anecdotal than generalizable. This study instead provides a spectrum of potential approaches institutions use to address the 3.g outcome. I extracted themes from the data, including courses wherein the outcome is evaluated, rubrics used, and mapping of program outcomes onto student outcomes.

\section{Results}

Contact information for 65 of the 66 institutions was found and emails sent to the identified contact people in the MET department and the library. I received responses from nine institutions. For the librarian survey, sixteen participants started the survey and nine completed it, for a participation rate of $14 \%$. Six of the respondents worked at institutions with more than 10,000 students, while 3 worked at institutions with between 1,000 and 10,000 students. The librarian survey was anonymous, but participants could elect to self-identify as part of the survey. Only two institutions could be identified as responding to both the survey and the selfstudy solicitation.

\section{Self-Study Results}


The documentation provided by ABET coordinators varied among institutions. I received four complete self-study documents (two of which included additional information beyond the selfstudy). Of the five remaining responding institutions, four sent part or all of Section 4 (Continuous Improvement) of their self study, which includes assessment data of student outcomes. Two sent their curriculum mapping, indicating which courses addressed the 3.g outcome. Two of those five institutions sent their Section 7.E (Library Services).

The responses embedded in the Section 4 data indicated that outcome 3.g tended to be addressed many times in the curriculum. Frequently, laboratory courses (where students typically write reports) were identified as such courses, as well as technical writing courses, often offered in an English department, technical drawing courses, and design courses. The broad scope of 3.g, including written, oral, graphical communication and ability to identify and use appropriate literature means that any time students are writing or giving presentations as part of a course, it might be counted as addressing that outcome. One institution even re-defined 3.g to be only "ability to communicate effectively through written, oral, and graphical means," i.e., dropping the literature use requirement entirely. Five institutions included information about the program outcome of "basic familiarity and use of industry codes, specifications, and standards," which was addressed most frequently in technical drawing courses, and twice in capstone courses.

With only one outcome that includes both communication and information literacy components, it was challenging to extract those courses that included IL. Most self-studies I received included brief syllabi of their courses, which often but not always included rubrics, assignments, and topics covered. This helped, but was not always sufficient to determine whether explicit information literacy expectations were embedded in a particular course.

In all but one case, the data extracted for ABET assessment (i.e., the data included in the selfstudy to demonstrate student achievement) came from the senior capstone design experience. The capstone rubrics, however, varied considerably in the information component required, with most rubrics not mentioning sources or references explicitly. All institutions reported student performance directly, but two also indicated student surveys (i.e., self-assessments) as sources of data for this outcome (they were transitioning out of that assessment method). Student performance was measured by course instructors, project partners, and, in one case, the institution's industrial advisory board.

As an example of an ambiguous rubric used for ABET assessment data (all quoted text describes the 'excellent' or 'proficient' category of an institution's rubric):

Oral Communication: "Team presents a professional, cohesive, interesting, and understandable overview of the project. All team members speak loudly and clearly."

Written Communication: "Poster is effective and professional in appearance, contains appropriate information presented in a logical, efficient and understandable way. Poster is error-free."

Alternatively, another institution's rubric included the following specific expectations: 
Identify and Formulate the Problem: Clearly identifies relevant known properties and appropriate assumptions...Gathers information in an appropriate form.

Research/Design Content: Excellent depth of research/design development with clear details, specific and thorough supporting evidence.

Another institution required documentation in multiple components of a research paper in a Devices and Circuits class:

Introduction: Context and background information is provided for the technical discussion that follows. Facts about the use of the technology and its importance are presented...

History: ...Cited work is used to support the facts presented...

Modern Approaches: ...A peer reviewed research publication is used as an example and summarized, highlighting promising approaches and results.

Works Cited: At least three relevant sources are cited, with a minimum of one being a peer reviewed publication. Citations are appropriately used and formatted.

The above example is the only institution that didn't use their capstone design to measure 3.g. Another institution used the VALUE rubric for Oral and Written Communication to assess 3.g), (Cooney [19] maps all of the VALUE rubrics to ETAC student outcomes) which contains an outcome "Sources and Evidence" with a rubric description at the 'proficient' level of

Demonstrates skillful use and citing of high-quality, credible, relevant sources to develop ideas that are appropriate for the discipline and genre of the writing. [20]

This institution also indicated that they had an embedded information literacy outcome,

The ability to recognize the extent and nature of information need, then to locate, evaluate, and effectively use the needed information. It involves designing, evaluating, and implementing a strategy to answer questions or achieve a desired goal.

Another institution did not have significant depth in their self-study, but they had an 'improvement plan' they were implementing that included a significant IL component. Their 3.g outcome was divided into written communication, oral communication components, as well as an expectation that students 'use citations for proposed work.' In their plan to enhance writing ability, in a technical writing course, they state that 'citation and referencing methods will also be taught...'

Another institution, while not appearing to measure information use, did include in their description of their capstone experience '....different needs of various projects require meeting a 
number of different standards and regulations.' They then mention a number of standards organizations that would be relevant to different types of design projects.

As evidence that, when information gathering is not explicitly required in a course, frequently students do not go that extra step, one institution has a link to student capstone project web sites, which include final reports deposited in their institutional repository. A spot check of ten reports yielded only two reports with any cited sources. One report had an incomplete reference to a textbook and a URL for a parts web site. The other had a single reference to a textbook.

Institutions that specifically addressed 'graphical communication' frequently tied that to beginning or advanced CAM courses/technical graphics. Three institutions explicitly connected such courses to the 'use of codes, specifications, and standards' program educational outcome, with one stating 'ability to produce working drawings and 3d assembly drawing, consistent with ANSI Y14 standards.’

In terms of Library Services, the depth and length of the section varied considerably from five lines to two and a half pages. It tended to be the case that smaller institutions had shorter writeups, and three of the largest institutions were part of a system of campuses, so write-ups of the resources and services available at each branch, or at least of the branch and the main campus were included. The Library Services section generally included facilities, hours of operation, reference availability (both in person and virtual). Less than half included a description of targeted instructional activities, although one mentioned that instruction 'was available' and another that general instruction was provided as part of the plan.

\section{Survey Results}

Seven out of the nine respondents contributed to section 7.E of the ABET self-study (the Facilities section dealing with Library Services). Five of those also met with the accreditation visiting committee and answered questions about the self-study and/or gave tours of appropriate spaces, while two institutions had no input into the self study. One institution was scheduled to meet with the committee, but was cancelled due to time constraints. Respondents indicated that, in the Library Services section, they included library facilities, collections (including budgets and important resources), services (instruction, reference help availability, and LibGuides).

Learning outcomes addressed by librarians beside 3.g, included 3.i: an understanding of and commitment to address professional and ethical responsibilities including a respect for diversity, and 3.k: a commitment to quality, timeliness, and continuous improvement. Additionally, there are program criteria specific to Mechanical Engineering Technology, which include, starting with the 2018-2019 criteria [21], e) Basic familiarity and use of industry codes, specifications, and standards, and before that (which would be the criterion in effect for the purposes of this study) h) Application of industry codes, specifications, and standards; and using technical communications, oral and written, typical of those required to prepare and present proposals, reports, and specifications [22].

Instructional support varied considerably among respondents (see Table 1). About half of respondents provide in-class instruction, including two of whom were embedded in the 
classroom. Three consulted in developing curriculum (who also indicated teaching in the classroom as well), while seven provide consultations outside the classroom. One respondent provided only a LibGuide to support students, although they also had general information literacy tutorials with quizzes as well, while two respondents have structured consultations with students and a LibGuide without any other involvement with the curriculum. No respondents teach an entire credit-bearing course, although one was listed as a co-instructor on the relevant MET courses.

Table 1: Libraries Instructional Support for MET programs

\begin{tabular}{|l|l|}
\hline Type of Support & Number of Responses \\
\hline In-class instruction & 5 \\
\hline Consultation on Curriculum & 3 \\
\hline Embedded in Classroom & 2 \\
\hline $\begin{array}{l}\text { Consultations with students outside the } \\
\text { curriculum }\end{array}$ & 7 \\
\hline LibGuides & 8 \\
\hline Other: Badges and Online Tutorials & 2 \\
\hline
\end{tabular}

In terms of the information literacy instruction, the most commonly provided instruction, indicated by two-thirds of the respondents, is in the senior capstone design course, while one institution provided instruction in all four years, and another in three out of four.

Table 2: Information Literacy Instruction by Course Type

\begin{tabular}{|l|l|}
\hline Course & Number of Responses \\
\hline Senior Capstone Design & 6 \\
\hline $3^{\text {rd }}$ year design & 1 \\
\hline $2^{\text {nd }}$ year Manufacturing/CAD & 2 \\
\hline First-Year Design & 2 \\
\hline First-year Fundamentals & 1 \\
\hline First-year Seminar & 1 \\
\hline Summer Bridge & 1 \\
\hline
\end{tabular}

The contributions of the librarian toward courses include the following:

"First-year introductory to design class, we have a flipped class activity in which students find sources and evaluate their quality...graded assignment, and graded final project that includes a bibliography."

“2nd year, MET course on production design and specifications...in class instruction, standards assignment. Students have the option to earn a badge if they do an exemplary job on the assignment."

"Capstone design - embedded with project teams...consult with them on their information needs." 
"We meet with the instructors to plan the session and a related annotated bibliography assignment. We then visit the classroom for a 90-minute inclass session focusing on the scholarly discourse in the engineering field; searching appropriate engineering databases; and evaluating sources. Librarians then correct a homework assignment related to the session. Librarians also visit other courses for embedded instruction as needed."

"I provide a libguide for all undergraduate engineering students. Our library also has information literacy video tutorials with quizzes online. “

"In-class presentation on library research, including articles, standards and patents. In-class presentation on preparing the final senior design report for open publication.. Provide support for preparing, cataloging, publishing the MET senior design reports in the institutional repository for open access."

"Provide an online directory of professional organizations for students to explore; deliver patent and intellectual property research and ethics instruction; incorporate ethical case studies into engineering research instruction.”

\section{Discussion}

Putting all the elements of written and oral communication and information literacy into a single student outcome means that the information literacy component of the outcome can easily be marginalized in the assessment process. Indeed one institution even rewrote their student outcome to eliminate 'everything after the semicolon,' explicitly ignoring the information component of the outcome. Frequently, the capstone design assessments were very broadly written, like 'effectively communicates,' without any apparent requirements for using or at least documenting external sources of information. Indeed, one repository of student capstone design reports showed only marginal documentation of external sources.

Two institutions' self-studies, however, reported oral, written, and information use as separate data points, so, there are definitely examples of better practices in existence. One institution even supplied a rubric that indicated multiple sections of the report that needed to be sourced to justify students' assertions. Dissemination of these successful examples of IL-integrated student outcomes might improve their adoption across more institutions.

There was not a correlation between size of the institution and the depth of information literacy integration. One of the largest institutions had a very strong instructional program, while a branch campus with only two professional librarians at the entire institution (although they had infrastructural support from the main campus) also had perhaps the deepest and best articulated information literacy assessment I found. Thus, it seems that it isn't the size that matters, so much as the interests of key individuals on campus. There was evidence at one institution that, when their students were found to be deficient in the 3.g outcomes, it opened up the opportunity for 
librarians to get involved and expand the department's conception of 3.g to include more information components.

Other places where the 3.g student outcome is addressed include laboratories, technical writing, and CAM/technical design courses. These might provide opportunities for librarians to introduce introductory information literacy concepts, as scaffolding for senior design information requirements. Technical graphics courses can introduce the use of standards [14], and laboratory courses can provide the opportunity for students to practice locating and citing technical documents, for example, that contain parts data, materials or device properties.

Librarians reported that they provide instruction or external consultations primarily in the capstone courses, although there are a couple examples of instructional programs that touch students multiple times in their academic careers. Certainly, LibGuides are a frequently used method of making information about information available to students.

\section{Conclusion}

Hopefully, this study will shine the light on the need for librarians to share best practices for engaging with their faculty in engineering technology departments to improve the integration of IL into the 3.g outcome and beyond. Engineering technology programs also would benefit from sharing their practices with their institution's librarians. Based on the results of this paper, librarians are an untapped resource when it comes to contributing to the assessment of students' 'identify and use appropriate technical literature,' for accreditation purposes. Librarians could be developing rubrics, advising on assignments, grading student bibliographies, and contributing in other ways. Instead, most librarians only actively contribute to the 7.E, Library Services, section of accreditation reports. Many librarian do describe their instructional program as part of this section, in addition to collections and study spaces, but that is one step removed from actually measuring impact on student performance. Finally, I would encourage others to utilize the methods from this paper to see how information literacy has been conceptualized and implemented in other programs of study.

\section{References}

[1] D. Riley and R. Piccinino, "Integrating information literacy into a first year mass and energy balances course.” Paper presented at 2009 Annual Conference \& Exposition, Austin, Texas. https://peer.asee.org/5347.

[2] M. Sapp Nelson and M. Fosmire, "Engineering librarian participation in technology curricular redesign: Lifelong learning, information literacy, and ABET Criterion 3.” Paper presented at the 2010 ASEE Annual Conference \& Exposition, Louisville, Kentucky. https://peer.asee.org/16183.

[3] ABET Criteria for Accrediting Engineering Technology Programs, Effective for Evaluations During the 2010-2011 Accreditation Cycle Incorporates all changes approved by the ABET Board of Directors as of October 31, 2009. ABET, Inc., Baltimore, MD. 
[4] ABET Criteria for Accrediting Engineering Technology Programs, Effective for Evaluations During the 2011-2012 Accreditation Cycle. Incorporates all changes approved by the ABET Board of Directors as of October 30, 2010.

[5] H. G. Ansell and R. V. Staus, "ET students' perceptions of the most important means of learning." Paper presented at the 2001 American Society for Engineering Education Annual Conference \& Exposition. Albuquerque, New Mexico. https://peer.asee.org/9233.

[6] L. Feldmann and J. Feldmann, "Developing information literacy skills in freshman engineering technology students," in Proceedings of the $30^{\text {th }}$ ASEE/IEEE Frontiers in Education Conference. Kansas City, MO, 2000. DOI: 10.1109/FIE.2000.896650

[7] K.H. Hill, M. M. Best, and A.P. Dalessio, "Information Literacy in the Engineering Technologies at Community College: A Literature Review." Community and Junior College Libraries, vol. 18, p. 151-167, 2012. DOI: 10.1080/02763915.2012.812920

[8] C.A. Erdmann and B.A. Harding, "Leveraging the Internet and limited on-campus resources to teach information literacy skills to future engineering practitioners." Paper presented at the 2010 ASEE Annual Conference and Exposition, Louisville, Ky. https://peer.asee.org/16479

[9] C. A. Erdmann and B. A. Harding, "Information literacy: Needs - Skills Assignments." In Proceedings of the 1988 ASEE Annual Conference, Portland, Oregon. vol. 5, p. 2073-2078, 1988.

[10] A. S. Van Epps, M. Sapp Nelson, M. Fosmire, and B. Harding, "Next generation of online tutorials: Finding technical information at Purdue." In Proceedings of the International Conference on Engineering Education, Coimbra, Portugal, September 3-7, $2007 .$.

[11] J. Bhatt, V. Genis, and J. Roberts, "Library experience for applied engineering technology students. Paper presented at the 2006 American Society for Engineering Education Annual Conference \& Exposition. Chicago, IL. https://peer.asee.org/68

[12] A. S. Khan, A. Karim, and J. A. McClain, "The state of the use of standards in engineering and technology education." Paper presented at the 2013 ASEE Annual Conference and Exposition, Atlanta, GA. https://peer.asee.org/22618

[13] R. Krahe, "Software engineering standards in the ECET curriculum." Paper presented at the 2005 ASEE Annual Conference and Exposition, Portland, OR. https://peer.asee.org/14220.

[14] M. Phillips, and P. McPherson, "Using everyday objects to engage students in standards education," in Proceedings of the 2016 Frontiers in Education Conference, Erie, PA, October 12-15, 2016. 10.1109/FIE.2016.7757698

[15] B. Harding and P. McPherson, "What do employers want in terms of employee knowledge of technical standards and the process of standardization?” Paper presented at the 2010 ASEE Annual Conference and Exposition, Louisville, Kentucky. https://peer.asee.org/16474 
[16] T. E. Pinelli, M. England, R. O. Barclay, and J. M. Kennedy, (1996) “The technical communications practices of engineering technology students: Results of the NASA/DOD Aerospace Knowledge Diffusion Research Project - The Phase 3 student surveys.” In Proceedings of the AIAA $34^{\text {th }}$ Aerospace Sciences Meeting and Exhibit, Reno, NV. AIAA Paper 96-0836.

[17] ABET Criteria for Accrediting Engineering Technology Programs, 2020 - 2021. ABET, Baltimore, MD, 2019. Available: https://www.abet.org/accreditation/accreditationcriteria/criteria-for-accrediting-engineering-technology-programs-2020-2021/. [Accessed January 22, 2020].

[18] ABET ETAC Side By Side Criteria Final 0101 19. ABET, Baltimore, MD. Available: http://www.abet.org/wp-content/uploads/2019/02/ETAC-Side-By-Side-Criteria-Final-01-0119.pdf. [Accessed, January 22, 2020.]

[19] E. M. Cooney, “Adapting the VALUE Rubrics to ABET ETAC Outcomes A-K.” Paper presented at the 2014 ASEE Annual Conference \& Exposition, Indianapolis, Indiana. https://peer.asee.org/20027.

[20] AACU, Written Communication VALUE Rubric. Association of American Colleges and Universities, Washington, DC, 2009. Available: https://www.aacu.org/value/rubrics/writtencommunication. [Accessed February 1, 2020.]

[21] ABET Criteria for Accrediting Engineering Technology Programs, 2018 - 2019. ABET, Baltimore, MD, 2019. Available: https://www.abet.org/accreditation/accreditationcriteria/criteria-for-accrediting-engineering-technology-programs-2018-2019/. [Accessed January 22, 2020].

[22] ABET Criteria for Accrediting Engineering Technology Programs, 2017 - 2018. ABET, Baltimore, MD, 2019. Available: https://www.abet.org/accreditation/accreditationcriteria/criteria-for-accrediting-engineering-technology-programs-2017-2018/. [Accessed January 22, 2020]. 


\section{Appendix A}

\section{Email Request to ABET ETAC Accredited MET BS programs}

Dear Professor XXXXX,

Thank you for your attention. I am seeking your assistance, as director of the MET BS program at [Institution], with a research project to understand the role of and extract best practices for information literacy in ABET ETAC student outcome 3.g. 'Ability to apply written, oral, and graphical communication in both technical and non-technical environment; and an ability to identify and use appropriate technical literature.'

I anticipate presenting the results at an upcoming ABET symposium and ASEE Annual Conference to share best practices on addressing and assessing 3.g student outcomes.

For the project, I would appreciate it if you could share the following information from your institution's most recent ABET self-study:

Criterion 4. Continuous Improvement, sections A-E (especially 4.B): related to the 3.g learning outcome

Criterion 5. Curriculum, B: Syllabi and/or grading rubrics for courses/activities that meet the 3.g learning outcome.

\section{Criterion 7.E Library Services}

I understand that this is an inconvenience for you, but any information you could provide will help improve how 3.g (which looks to continue as ' 3 ' in the proposed new student outcomes for 2019) is reported in ETAC programs.

The most important information I'm looking for is how you've defined outome 3.g (i.e., has it been mapped to other institutional program outcomes), what criteria (e.g., rubrics) are being used to assess the 3.g. outcome, and where in the curriculum 3.g. is being addressed, reinforced, and assessed...I've found that the location of information varies from study to study, but generally is contained section 4 .

All information shared will be kept confidential and only reported anonymously, in aggregate. I will be happy to provide a summary of the results to you as well, if you are interested.

Thank you for your consideration, and let me know if I can answer any questions you have about this project, or if I should direct my request to someone else at [Institution]. 


\section{Appendix B}

\section{Survey Sent to MET Liaison Librarians}

Thank you for participating in this survey about information literacy and ABET accreditation in engineering technology. I am specifically interested in understanding the scope of library interaction with Mechanical Engineering Technology BS accredited programs, to share best practices with both engineering technology faculty and librarians.

ABET accreditation requires students to meet several student learning outcomes, including outcome 3.g. : an ability to apply written, oral, and graphical communication in both technical and non-technical environments; and an ability to identify and use appropriate technical literature;

I would appreciate it if you could answer a few questions about your interactions with your institution's MET accreditation process. I anticipate the survey will take less than 10 minutes. All survey information will be kept confidential and only reported in aggregate.

This survey has been determined to be exempt by Purdue's IRB \# 86532176.

I acknowledge that my participation is completely voluntary, I may skip any answers and stop participating at any time.

How have you/your library contributed to your institution's most recent ABET selfstudy/accreditation for their Mechanical Engineering Technology BS program? Check all that apply.

Contributed to Continuous Improvement (Section 4): includes assessment plan, rubrics, success targets

Contributed to Curriculum (Section 5): includes syllabi of courses

Contributed to Library Services (Section 7.E)...includes description of facilities and services

Met with visiting committee of external evaluators

Did not contribute

Other, please specify:

Please, briefly describe specifically how you contributed to the selfstudy/ accreditation visit.

What ABET student learning outcomes beside 3.g do you contribute to? Check all that apply.

3. a. an ability to select and apply the knowledge, techniques, skills, and modern tools of the discipline to broadly-defined engineering technology activities;

3. b. an ability to select and apply a knowledge of mathematics, science, 
engineering, and technology to engineering technology problems that require the application of principles and applied procedures or methodologies;

3. c. an ability to conduct standard tests and measurements; to conduct, analyze, and interpret experiments; and to apply experimental results to improve processes;

3. d. an ability to design systems, components, or processes for broadly-defined engineering technology problems appropriate to program educational objectives;

3. e. an ability to function effectively as a member or leader on a technical team;

3. f. an ability to identify, analyze, and solve broadly-defined engineering technology problems;

3. h. an understanding of the need for and an ability to engage in self-directed continuing professional development;

3. i. an understanding of and a commitment to address professional and ethical responsibilities including a respect for diversity;

3. j. a knowledge of the impact of engineering technology solutions in a societal and global context;

3. k. a commitment to quality, timeliness, and continuous improvement.

Other student outcomes, please specify:

What instructional support do you provide to meet the ABET student learning outcomes?

Teach credit bearing course(s) as instructor of record (i.e., assign final course grades)

Provide other in-class instruction

Consult with MET instructors on curriculum development

Consult with students in the classroom (e.g., embedded support)

Consult with students outside the classroom

Create online instructional materials (e.g., LibGuides)

Do not provide support

Other: Please specify:

Please describe specifically how you contribute to meeting the MET ABET student learning outcomes.

Which courses do you interact with in the MET curriculum? (E.g., senior design, firstyear learning community, mechatronics)

How large is your institution?

Less than 1,000 students

1,000-10,000 students

Greater than 10,000 students

Would you be willing to be contacted to answer any follow-up questions? If so, please enter your email address. 